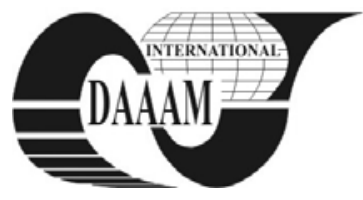

Annals of DAAAM for 2011 \& Proceedings of the 22nd International DAAAM Symposium, Volume 22, No. 1, ISSN 1726-9679 ISBN 978-3-901509-83-4, Editor B. Katalinic, Published by DAAAM International, Vienna, Austria, EU, 2011 Make Harmony between Technology and Nature, and Your Mind will Fly Free as a Bird Annals \& Proceedings of DAAAM International 2011

\title{
REGIONAL COMPETITIVENESS EVALUATION IN ROMANIA
}

\section{NEGRU STRAUTI, G[abriela]; MAISTOR, S[orin] - I[oan]; MOCAN, M[arian] L[iviu] \& PUGNA, A[drian] P[avel]}

\begin{abstract}
The paper approach one of the key concept uses in economic and social analysis of the last decades: regional competitiveness. In this methodological approach are indentified series of social and economical indicators which are considered relevant in evaluation of regional competitiveness. The analysis was made for year 2009, gathering data for the eight development regions of Romania: North-West $(N-W)$, Center (C), North-East (N-E), South-East (S-E), BucharestIlfov (B-I), South (S), South-West (S-W) and West (W)

Key words: regional competitiveness, evaluation, utility, quantification
\end{abstract}

\section{INTRODUCTION}

Regional competitiveness is the capacity of one region to generate a level of income and a sustainable growth of the living standard in a durable manner and in conditions of competition. On the other hand, regional competitiveness depends on the productivity and accessibility of markets, on the level of workforces' qualification and on the institutional factors like social capital for entrepreneurial culture to encourage cooperation and initiative and contribute at efficiency for public administration (Negru Strauti et al., 2010).

So, regional competitiveness can be defined as the ability of a region and of its public authority to maintain the local base of qualified workforce and companies, and to attract foreign investments (Negru-Strauti \& Taucean, 2008).

There are nevertheless factors that affect competitiveness but which are not easily quantitatively, estimated or approximated. In this category we have for example governmental policies, venture capital and risk capital indicators, firms' rate of registration, industrial conglomerates.

In consequence, to characterize competitiveness of a region it is necessary to analyze some key aspects of regional economic development level.

This paper provides a competitiveness evaluation that helps identifying successful development regions in Romania, and an idea of the broad issues to be investigated in a more detailed analysis in the future.

\section{METHOD OF QUANTIFYING RC}

Some of the previous researches (Martin, 2006), were based on comparative and regression analysis, across a wide set of primarily micro-economic indicators of the work on regional competitiveness, that is empirically driven, there are two distinguishable approaches: studies that analyse regional competitiveness as a cumulative outcome of factors; studies that focus on a particular driver of competitiveness. The empirical section lists the driving factors that have been used in previous studies to explain regional performance. The breakdown of GDP per capita into constituent parts relation (1) provides an initial set of output indicators, each of which can be explained in terms of its own set of drivers. On the other hand, GDP per head, provides an, albeit incomplete, indicator of the average well-being of the population. For analytical purposes this can be decomposed in elements presented in relation (1).

$$
\frac{G D P}{P}=\frac{G D P}{T H W} \cdot \frac{T H W}{E} \cdot \frac{E}{W A P} \cdot \frac{W A P}{P}
$$

Where: GDP/THW - Productivity; THW/E- Work Leisure; E/WAP - Employment Rate; WAP/P Dependency Rate; GDP - Gross Domestic Product; THW - Total Hours Worked; E - Employment; WAP - Working Age Population.

Some interrelation is likely between these indicators, e.g. highly productive regions using skilled labour may well also display high rates of employment. However, regional productivity - measured as GDP per hour worked - is seen as a primary motor of improved regional GDP per head.(***, 2010)

A more affordable model, which still provide full information on the assessment of regional competitiveness and could be correlated with previous researches and can be developed using a series of social and economical indicators provided by statistics made for the eight development regions (DR) of Romania.

\section{DATA AND METHODOLOGY}

Proposed methodology aims to range the DR of Romania in terms of competitiveness through series of social and economical indicators that were aggregated in order to establish a high level of accuracy for the final results.

The values for selected indicators are data for year 2009, identified by the national statistics. (***, 2010)

\subsection{Social indicators}

The social indicators shown (Tab. 1) are average gross earning (AvGE) - represents the ratio between the amounts paid to employees by companies and the average number of employees, life expectancy (LE) - statistically determined value which represents the average number of years of life that a person will live, number of employees in the economy (NEE) - the number of persons engaged in the work field for a specific economy, total monthly income (TMI) - represents the income of a person from different sources, not only cash income.

For a more accurate analysis it was used the linear interpolation (2).

\begin{tabular}{|c|c|c|c|c|}
\hline DR & $\begin{array}{c}\text { AvGE } \\
\text { (RON/empl.) }\end{array}$ & $\begin{array}{c}\text { LE } \\
\text { (years) }\end{array}$ & $\begin{array}{c}\text { NEE } \\
\text { (number) }\end{array}$ & $\begin{array}{c}\text { TMI } \\
\text { (RON/pers.) }\end{array}$ \\
\hline N-W & 1566 & 72.82 & 9265 & 772.60 \\
\hline C & 1645 & 73.62 & 7568 & 791.25 \\
\hline N-E & 1629 & 73.38 & 6528 & 706.62 \\
\hline S-E & 1699 & 73.04 & 5410 & 717.40 \\
\hline B-I & 2488 & 73.07 & 4845 & 1182.32 \\
\hline S & 1748 & 74.94 & 71846 & 765.14 \\
\hline S-W & 1776 & 73.08 & 3884 & 702.32 \\
\hline W & 1712 & 72.96 & 11715 & 853.71 \\
\hline
\end{tabular}

Tab. 1 Social indicators table 


$$
u_{i j}=\frac{a_{i j}-\min a_{i j}}{\max a_{i j}-\min a_{i j}}
$$

Where: $\mathrm{a}_{\mathrm{ij}}$ - the corresponding value for each indicator.

Using the above relation the utilities table for social indicators was developed (Tab. 2).

\begin{tabular}{|c|c|c|c|c|c|}
\hline $\mathrm{DR}$ & $\mathrm{U}_{\text {AvGE }}$ & $\mathrm{U}_{\mathrm{LE}}$ & $\mathrm{U}_{\text {NEE }}$ & $\mathrm{U}_{\mathrm{TMI}}$ & $\Sigma \mathrm{U}_{\text {ij-so }}$ \\
\hline $\mathrm{N}-\mathrm{W}$ & 0 & 0 & 0.07917 & 0.14641 & 0.2255 \\
\hline $\mathrm{C}$ & 0.08568 & 0.37735 & 0.05420 & 0.18527 & 0.7025 \\
\hline $\mathrm{N}-\mathrm{E}$ & 0.06833 & 0.26415 & 0.03890 & 0.00895 & 0.3803 \\
\hline $\mathrm{S}-\mathrm{E}$ & 0.14425 & 0.10377 & 0.02245 & 0.03141 & 0.3018 \\
\hline $\mathrm{B}-\mathrm{I}$ & 1 & 0.11792 & 0.01414 & 1 & 2.1320 \\
\hline $\mathrm{S}$ & 0.19739 & 1 & 1 & 0.13087 & 2.3282 \\
\hline $\mathrm{S}-\mathrm{W}$ & 0.22776 & 0.12264 & 0 & 0 & 0.3504 \\
\hline $\mathrm{W}$ & 0.15835 & 0.06603 & 0.11522 & 0.31539 & 0.6549 \\
\hline
\end{tabular}

Tab. 2 Table of utilities for social indicators

\subsection{Economical indicators}

The economical indicators shown (Tab. 3) are turnover obtained by the eight regions of development, exports, Active Local Units (ALU) - represents the number of local companies that operated in the analyzed period of time, at a identifiable address, Gross Domestic Product (GDP) (***, 2011).

\begin{tabular}{|c|c|c|c|c|}
\hline DR & $\begin{array}{c}\text { Turnover } \\
\text { (mil.RON) }\end{array}$ & $\begin{array}{c}\text { Exports } \\
\text { (th. eur) }\end{array}$ & $\begin{array}{c}\text { ALU } \\
\text { (number) }\end{array}$ & $\begin{array}{c}\text { GDP } \\
\text { (RON) }\end{array}$ \\
\hline N-W & 87251 & 3900393 & 77731 & 56652.1 \\
\hline C & 89907 & 3599728 & 67734 & 55178.7 \\
\hline N-E & 62643 & 1241400 & 61000 & 51979.4 \\
\hline S-E & 90059 & 3374317 & 65939 & 52988.7 \\
\hline B-I & 317303 & 6117430 & 130328 & 127008.4 \\
\hline S & 102056 & 4798348 & 60108 & 65309.4 \\
\hline S-W & 50778 & 1637105 & 40166 & 39805.2 \\
\hline W & 67987 & 4114073 & 52595 & 48641.3 \\
\hline
\end{tabular}

Tab. 3 Economical indicators table

Using the relation (2) the utilities table for economical indicators was developed (Tab. 4).

\begin{tabular}{|c|c|c|c|c|c|}
\hline $\mathrm{DR}$ & $\mathrm{U}_{\text {Turnover }}$ & $\mathrm{U}_{\text {Exports }}$ & $\mathrm{U}_{\mathrm{ALU}}$ & $\mathrm{U}_{\mathrm{GDP}}$ & $\Sigma \mathrm{U}_{\text {ij-ec }}$ \\
\hline $\mathrm{N}-\mathrm{W}$ & 0.13684 & 0.54531 & 0.41663 & 0.19319 & 1.2919 \\
\hline $\mathrm{C}$ & 0.14681 & 0.48365 & 0.30576 & 0.17629 & 1.1125 \\
\hline $\mathrm{N}-\mathrm{E}$ & 0.04451 & 0 & 0.23107 & 0.13960 & 0.4151 \\
\hline $\mathrm{S}-\mathrm{E}$ & 0.14738 & 0.43742 & 0.28585 & 0.15118 & 1.0218 \\
\hline $\mathrm{B}-\mathrm{I}$ & 1 & 1 & 1 & 1 & 4 \\
\hline $\mathrm{S}$ & 0.19239 & 0.72947 & 0.22118 & 0.29246 & 1.4355 \\
\hline $\mathrm{S}-\mathrm{W}$ & 0 & 0.08115 & 0 & 0 & 0.0811 \\
\hline $\mathrm{W}$ & 0.06456 & 0.58914 & 0.13785 & 0.10132 & 0.8928 \\
\hline
\end{tabular}

Tab. 4 Table of utilities for economical indicators

\begin{tabular}{|c|c|c|c|c|c|}
\hline $\mathrm{DR}$ & $\Sigma \mathrm{U}_{\text {ij-so }}$ & $\mathrm{P}_{1}$ & $\Sigma \mathrm{U}_{\text {ij-ec }}$ & $\mathrm{P}_{2}$ & $\Sigma \mathrm{U}_{\text {ij-fin }}$ \\
\hline $\mathrm{N}-\mathrm{W}$ & 0.2255 & 0.0902 & 1.2919 & 0.7751 & 0.87 \\
\hline $\mathrm{C}$ & 0.7025 & 0.2810 & 1.1125 & 0.6675 & 0.95 \\
\hline $\mathrm{N}-\mathrm{E}$ & 0.3803 & 0.1521 & 0.4151 & 0.2491 & 0.40 \\
\hline $\mathrm{S}-\mathrm{E}$ & 0.3018 & 0.1207 & 1.0218 & 0.6131 & 0.73 \\
\hline $\mathrm{B}-\mathrm{I}$ & 2.1320 & 0.8528 & 4 & 2.4 & 3.25 \\
\hline $\mathrm{S}$ & 2.3282 & 0.9313 & 1.4355 & 0.8613 & 1.79 \\
\hline $\mathrm{S}-\mathrm{W}$ & 0.3504 & 0.1401 & 0.0811 & 0.0487 & 0.19 \\
\hline $\mathrm{W}$ & 0.6549 & 0.2619 & 0.8928 & 0.5357 & 0.80 \\
\hline
\end{tabular}

Tab. 5 Table of aggregated utilities

The table 5 contains the aggregated utilities for all the considered indicators, where the global utility $\left(\mathrm{U}_{\mathrm{ij}-\text { fin }}\right)$ was calculated assuming that the utilities for the social indicators $\left(\mathrm{U}_{\mathrm{ij}-\mathrm{so}}\right)$ weight $40 \%$ in the final result, and the utilities for the economical indicators $\left(\mathrm{U}_{\mathrm{ij} \text {-ec }}\right)$ weight $60 \%$. In accordance with that the values for $\mathrm{P}_{1}$ and $\mathrm{P}_{2}$ were obtained (Tab.5).
The final results are presented in Figure 1.

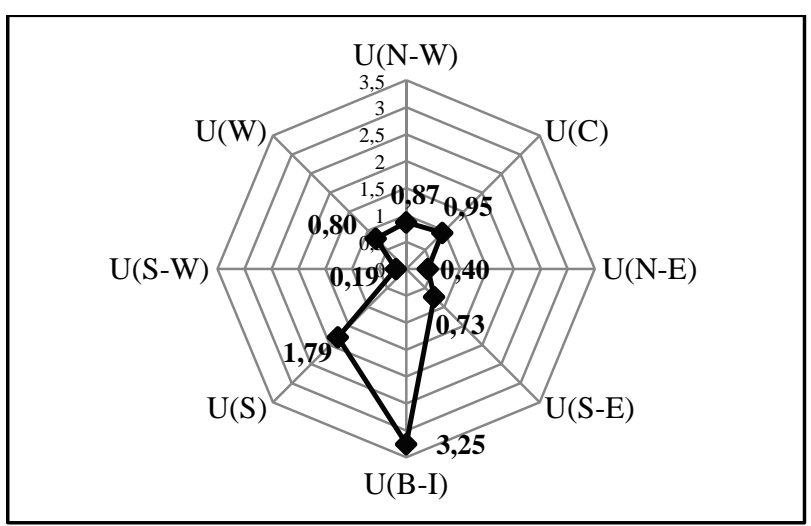

Fig. 1 Evaluation of competitiveness for DR of Romania

\section{CONCLUSIONS}

Research aspect is based on the use of ten socio-economical indicators that offer a clear preview of the regional competitiveness level in Romania, and can be extended with technical development and foreign investements made in the past years, for a more accurate result.

The objective of this research has been reached by designing a more affordable model, which still provide full information on the assessment of regional competitiveness and could be correlated with previous researches.

Based on the obtained results it has been appreciate which are the development regions with high competitiveness.

First we must observe that the data we processed bring out the following conclusions concerning regional entrepreneurial development:

- Bucharest-Ilfov region is by far in front of the classification with best results for all indicators; for other groups there is a combination of favorable and unfavorable characteristics which need an interpretation from case to case - the South region with entrepreneurial potential holds some advantages that should be exploited further.

This study recognizes the existing of different practices concerning regional initiatives, but the capacity of starting up of prosperous business can be use with success in any region.

\section{REFERENCES}

Martin, R.L;(2006). A Study on the Factors of Regional Competitiveness, Available from:

http://ec.europa.eu/regional_policy/sources/docgener/studie s/pdf/3cr/competitiveness.pdf, Accessed: 2011-06-25

Negru Strauti, G.; Pugna, A. P.; Mocan, M. L. \& Cismariu, L. (2010). Model for Regional Competitiveness Evaluation for Romania, Annals of DAAAM for 2010 \& Proceedings of the 21st International DAAAM Symposium, 20-23rd October 2010, Zadar, Croatia, ISSN 1726-9679, ISBN 9783-901509-73-5, Katalinic, B. (Ed.), pp. 0417-0418, Published by DAAAM International Vienna, Vienna

Negru-Strauti, G., Taucean, I. (2008), Regional competitiveness evaluation for Romania, Annals of Oradea University, Fascicle of Management and Technological Engineering Volume XVII (VII), ISSN 1583-0691, pg. 2554-2561

*** (2010)http://www.adrcentru.ro Elemente de competitivitate regionala.Regiunea Centru, Accessed on: 2011-07-15

*** (2010) Statistical Yearbook of Romania - time series 19902009 National Institute of Statistics, ISSN: 1841-5431,2010

*** (2011) Projection of the main territorial socio-economical indicators until 2014, Available from:

http://www.cnp.ro/user/repository/prognoza_regiuni_2011_ 2014.pdf, Accessed: 2011-07-15 